\title{
Uji Aktivitas Antioksidan Kombinasi Ekstrak Daun Kersen (Muntingia calabura Linn.) dan Daun Sirsak (Anonna muricata Linn.) Metode DPPH (2,2-diphenyl-1- picrilhidrazyl)
}

\begin{abstract}
Antioxidant Activity Test Combination of Kersen Leaf Extract (Muntingia calabura Linn.) and Soursop Leaf (Anonna muricata Linn.) DPPH (2,2-diphenyl-1-picrilhidrazyl) Method
\end{abstract}

Tri Harningsih* dan Wimpy

Program Studi Analis Kesehatan Sekolah Tinggi Ilmu Kesehatan Nasional, Surakarta.

*Corresponding author : tri.harningsih@gmail.com

\section{ABSTRAK}

Daun kersen dan daun sirsak merupakan tanaman serta dapat digunakan menjadi obat. Daun kersen memiliki kandungan alkaloid, flavonoid, saponin dan steroid. Daun sirsak memiliki kandungan alkaloid, flavonoid, saponin, dan tanin. Senyawa-senyawa tersebut memiliki kemampuan sebagai antioksidan untuk menghambat radikal bebas. Penelitian ini bertujuan untuk mengetahui aktivitas antioksidan kombinasi ekstrak daun kersen dan ekstrak daun sirsak dan dibandingkan dengan bentuk tunggal keduanya dalam menangkal radikal bebas.

Penelitian dilakukan sejak bulan Februari sampai Juli 2018 di B2P2TOOT Tawangmangu dan Laboratorium Kimia STIKES Nasional. Jenis penelitian ini adalah eksperimental dengan teknik quota sampling.

Hasil penelitian menunjukkan bahwa kombinasi daun kersen dan daun sirsak 2:1 memiliki nilai IC $C_{50}$ sebesar 6,9126 ppm dan dikategorikan sangat kuat. Nilai $I_{50}$ bentuk tunggal daun kersen sebesar 15,9999 ppm dan dikategorikan sangat kuat. Bentuk tunggal daun sirsak sebesar 116,5376 ppm dan dikategorikan sedang. Kombinasi daun kersen dan daun sirsak 1:1 sebesar 28,1075 ppm termasuk dalam kategori sangat kuat. Kombinasi daun kersen dan daun sirsak 1:2 sebesar 28,4886 dan dikategorikan sangat kuat.

Aktivitas antioksidan kombinasi ekstrak daun kersen dan daun sirsak sangat kuat dibandingkan bentuk tunggal keduanya. Kombinasi ekstrak daun kersen dan ekstrak daun sirsak 2:1 memiliki aktivitas antioksidan yang sangat kuat.

Kata kunci: antioksidan, daun kersen, daun sirsak, quota sampling, DPPH.

\section{ABSTRACT}

Kersen and Soursop are plants which can be used as medicine. Kersen leaf have alkaloids, flavonoid, saponins and steroid. Soursop leaf have alkaloids, flavonoid, saponins, and tanin. The compounds can be used as an antioxidant for free radical inhibitor. The aim of this study is to find out combination the antioxidant activity between kersen leaf extract and soursop leaf extract and compared to the singular in counteracting free radical DPPH.

The research was done during February to July 2018 at B2P2TOOT Tawangmangu and Chemical Laboratory of STIKES Nasional. The type of this research was experimental with quota sampling technique.

The result of this research showed that combination of kersen and soursop leaf extract at 2:1 had IC $C_{50}$ value of 6,9126 ppm and was categorized as strong antioxidant. The value of $I_{50}$ singular of kersen leaf was 15,9999 ppm and was categorized as very strong. Singular of soursop leaf was 116,5376 ppm and was categorized as medium. Combination of kersen and soursop leaf extract at 1:1 had $I C_{50}$ value of 28,1075 ppm, included in very strong category and combination of kersen leaf and soursop leaf at 1:2 had IC ${ }_{50}$ value of 28,4886 ppm included in very strong category.

Antioxidant combination of kersen leaf and soursop leaf extract activity was stronger than the singular. Combination of kersen leaf and soursop leaf extract of 2:1 had the strongest antioxidant activity.

Keywords : antioxidant, kersen leaf, soursop leaf, quota sampling, DPPH.

\section{PENDAHULUAN}

Kemajuan teknologi dapat memicu terbentuknya masyarakat modern, namun penggunaan berbagai teknologi tersebut dapat mengakibatkan timbulnya efek samping berupa pencemar- an yang dapat menimbulkan berbagai macam gangguan kesehatan. Sumber pencemar dapat berasal dari asap kendaraan bermotor, asap rokok dan kebakaran hutan (Romansyah, 2011.) Pencemaran yang terjadi disertai pola makan 
yang tidak tepat dapat memicu terbentuknya radikal bebas didalam tubuh. Radikal bebas adalah molekul yang mempunyai satu atau lebih elektron bebas yang tidak berpasangan, sehingga mudah menarik elektron dari molekul lainnya sehingga radikal bebas tersebut menjadi lebih reaktif(Sumiyani, 2007).

Radikal bebas akan merusak sel dan jaringan di dalam tubuh, sehingga menimbulkan berbagai penyakit degeneratif, antara lain kanker, penuaan dini, dan kardiovaskuler. Radikal bebas dapat dicegah dengan adanya senyawa antioksidan. Antioksidan merupakan senyawa yang dapat meredam kerja radikal bebas dan mengubahnya menjadi senyawa non radikal. Antioksidan mampu menetralkan radikal bebas atau bahan yang dapat mencegah sistem biologi tubuh dari efek yang merugikan yang timbul dari proses atau pun reaksi yang menyebabkan oksidasi yang berlebihan. Kersen merupakan salah satu tumbuhan yang berpotensi sebagai antioksidan (Kuntorini dkk., 2013). Hasil penelitian uji fitokimia pada daun kersen terdapat adanya flavonoid, triterpenoid, alkaloid, saponin dan steroid (Arum dkk., 2012). Penelitian sebelumnya daun kersen memiliki aktivitas antioksidan dengan nilai $\mathrm{IC}_{50}$ sebesar 18,214 ppm (Kuntorini dkk., 2013). Senyawa bioaktif dan antioksidan seperti alkaloid, tanin, flavonoid, dan saponin banyak terdapat pada daun sirsak. Senyawa-senyawa tersebut memiliki kemampuan sitotoksik yang dapat menghambat dan mereduksi radikal bebas (Handayani dkk, 2013).

Penelitian sebelumnya daun sirsak memiliki aktivitas antioksidan dengan nilai $\mathrm{IC}_{50}$ sebesar 22,25 ppm (Tambunan dkk., 2012 ). Tanaman kersen dan sirsak merupakan tanaman yang dapat berbuah dan sering dikonsumsi oleh masyarakat. Selain buahnya yang bermanfaat, daun dari tanaman kersen dan sirsak dapat dimanfaatkan sebagai antioksidan yang dapat menangkal radikal bebas. Kombinasi beberapa antioksidan dapat memberikan aktivitas anti- oksidan lebih besar daripada bentuk tunggalnya, seperti kombinasi ekstrak sarang semut dan teh hitam bentuk kombinasi menunjukkan hasil yang lebih baik daripada bentuk tunggal keduanya (Utomo, 2012).

Berdasarkan uraian tersebut maka peneliti tertarik untuk melakukan penelitian dengan judul "Uji Aktivitas Antioksidan Kombinasi Ekstrak Daun Kersen (Muntingia calabura L.) dan Daun Sirsak (Anonna muricata L.) Metode DPPH. Tujuan dari penelitian adalah untuk mengetahui perbedaan aktivitas antioksidan kombinasi ekstrak daun kersen dan ekstrak daun sirsak bila dibandingkan dengan aktivitas antioksidan pada bentuk tunggalnya serta untuk mengetahui kombinasi yang memberikan aktivitas antioksidan terbaik bila dibandingkan dengan bentuk tunggal keduanya.

\section{METODOLOGI PENELITIAN}

\section{Alat dan Bahan}

Alat yang digunakan pada penelitian ini yaitu Spektrofotometer UV-Visibel (AE LABS80-1S), neraca elektrik Acis, pipet tetes, kertas saring, rotary evaporator, alat-alat gelas berupa labu ukur Iwaky Pyrex, gelas ukur Iwaky Pyrex, gelas beker Iwaky Pyrex, pipet ukur, kaca arloji, corong, tabung reaksi, erlenmeyer Iwaky Pyrex, batang pengaduk, oven, botol vial, cawan penguap, spatula, bejana maserasi, vortex.

Etanol $96 \%$, serbuk $\mathrm{Mg}, \mathrm{HCl}$ pekat, amyl alcohol, butanol, $\mathrm{CHCl}_{3}, \mathrm{NaOH}, \mathrm{H}_{2} \mathrm{SO}_{4}$, pereaksi wagner, mayer, dragendorf, $\mathrm{FeCl}_{3}$ $5 \%, \mathrm{H}_{2} \mathrm{SO}_{4}$, ether, asam asetat anhidrat, alumunium foil, larutan induk vitamin $\mathrm{C}$, serbuk DPPH.

\section{Pengumpulan bahan}

Daun kersen harus segar, pengambilan daun kersen pada daun yang tua lalu dibersihkan. Daun segar dikeringkan dengan menggunakan oven pada suhu $40{ }^{\circ} \mathrm{C}$ (kuntorini dkk., 2013). Daun sirsak harus segar pengambilan daun sirsak urutan ke-5 dari pucuk dalam satu ranting. 
Daun segar dikeringkan dengan menggunakan oven pada suhu $40{ }^{\circ} \mathrm{C}$ (Zuhud, 2011)

\section{Prosedur pembuatan ekstrak}

Sebanyak 250 gram sampel yang sudah dike-ringkan dan dihaluskan ditambah dengan $2500 \mathrm{~mL}$ etanol $96 \%$ perbandingan 1:10. Larutan tersebut di- maserasi dengan cara dimasukkan dalam bejana maserasi, tutup dan dibiarkan selama 5 hari terlin-dung dari cahaya sambil diaduk dan disaring dengan kertas saring sehingga didapatkan maserat. Maserat diuapkan pada suhu $40{ }^{\circ} \mathrm{C}$ sampai didapatkan ekstrak kental selanjutnya ditimbang untuk mengetahui bobot sampel yang diperoleh.

\section{Pemeriksaan fitokimia}

\section{1) Alkaloid}

Ada 3 uji untuk mengetahui adanya senyawa alkaloid dalam sampel : sampel ditambah dengan 15 tetes $\mathrm{H}_{2} \mathrm{SO}_{4} 2 \mathrm{~N}$, kemudian bagi menjadi 3 tabung, tabung pertama tambahkan 5 tetes reagen dragendrof (hasil positif membentuk endapan merah sampai jingga), tabung kedua tambahkan 5 tetes reagen mayer (hasil positif membentuk endapan putih kekuningan), tabung ketiga tambahkan 5 tetes reagen wagner (hasil positif membentuk endapan coklat).

2) Flavonoid

Sampel ditambahkan $\pm 0,1 \mathrm{mg}$ serbuk $\mathrm{Mg}$ dan $\pm 0,4 \mathrm{~mL}$ amyl alkohol dan $4 \mathrm{~mL}$ alkohol kemudian dikocok. Adanya warna merah, kuning atau jingga pada lapisan amil alkohol menunjukkan adanya se- nyawa flavonoid.

3) Tanin

Sampel ditambahkan $\mathrm{FeCl}_{3} 5 \%$. Jika terbentuk warna hitam kehjauan atau hitam kebiruan maka terdapat sampel me- gandung tanin.

4) Steroid

Sampel dilarutkan dalam $2 \mathrm{~mL}$ kloroform dalam tabung reaksi yang kering. Kemudian ditambahkan 10 tetes asetat anhidrat dan 3 tetes asam sulfat pekat. Terbentuknya larutan berwarna merah untuk pertama kali kemudian berubah menjadi biru dan hijau menunjukkan reaksi positif.

5) Saponin

Saponin dapat dideteksi dengan uji busa dalamair panas. Adanya busa yang stabil dalam 30 menit dan tidak hilang pada penambahan 1 tetes $\mathrm{HCl} 2 \mathrm{~N}$ menunjukkan adanya saponin.

\section{Pembuatan larutan induk DPPH}

Ditimbang sebanyak 10,0 mg serbuk DPPH dilarutkan dalam $100 \mathrm{~mL}$ etanol $96 \%$ sehingga didapatkan larutan DPPH konsentrasi 100 ppm. Larutan disimpan pada suhu rendah dan terlindung dari sinar matahari untuk segera digunakan (Sumiyani, 2007).

\section{Pembuatan larutan kerja DPPH}

Pembuatan larutan DPPH 40 ppm dilakukan dengan cara memipet larutan DPPH 100 ppm sebanyak 40,0 $\mathrm{mL}$ kemudian ditambahkan etanol $96 \%$ dalam labu ukur 100,0 mL (Sumiyani, 2007).

\section{Skrining panjang gelombang maksimal}

Larutan DPPH 40 ppm sebanyak 3,0 mL ditambah dengan larutan blanko etanol sebanyak 1,5 mL. kemudian baca absorbansinya pada panjang gelombang ( $\lambda$ ) $400-700 \mathrm{~nm}$. Setelah itu buat kurva absorbansi dimana panjang gelombang dengan absorban tertinggi adalah panjang gelombang maksimum. Selanjutnya semua pengukuran dilakukan pada panjang gelombang maksimum tersebut (Sumiyani, 2007).

\section{Operating time}

Operating time dilakukan dengan cara 1,5 $\mathrm{mL}$ larutan kontrol ditambah 3,0 mL larutan DPPH 40 ppm. Larutan uji tersebut diukur pada menit ke-44 pada panjang gelombang maksimum yang diperoleh dari skrining panjang gelombang maksimal sampai diperoleh 
absorbansi yang stabil.

\section{Pengukuran aktivitas antioksidan pada ekstrak daun kersen}

Ditimbang ekstrak daun kersen sebanyak 20,0 mg dilarutkan dengan 100,0 mL etanol, hingga diperoleh konsentrasi 200 ppm, kemudian dilakukan pengenceran sehingga diperoleh larutan sampel dengan konsentrasi (2, 4, 6, 8, 10, 12 ppm). Dari masing - masing konsentrasi dipipet $1,5 \mathrm{~mL}$ larutan sampel kemudian ditambahkan 3,0 mL larutan DPPH 40 ppm, campuran tersebut diinkubasi pada suhu ruang. Kemudian campuran dimasukkan dalam kuvet, dan diukur absorbansinya.

\section{Pengukuran aktivitas antioksidan pada ekstrak daun sirsak}

Ditimbang ekstrak daun sirsak sebanyak 20,0 mg dilarutkan dengan 100,0 $\mathrm{mL}$ etanol 96 $\%$, hingga diperoleh konsentrasi 100 ppm, kemudian lakukan pengenceran sehingga diperoleh larutan sampel dengan konsentrasi (5, $10,15,20,25,30$ ppm). Penentuan aktivitas antioksidaan setiap konsentrasi dipipet $1,5 \mathrm{~mL}$ larutan sampel kemudian ditambah-kan 3,0 mL larutan DPPH 40 ppm, campuran campuran tersebut diinkubasi pada suhu ruang. Kemudian campuran dimasukkan dalam kuvet, dan diukur absorbansinya.

\section{Pengukuran aktivitas antioksidan kombinasi ekstrak daun kersen dan ekstrak daun sirsak dengan perbandingan (1:1) (2:1) dan (1:2).}

Pembuatan konsentrasi dari perbandingan (1:1) (1:2) dan (2:1) diperoleh dari pemipetan dari konsen-trasi 200 ppm ekstrak daun kersen dan konsentrasi 200 ppm dari ekstrak daun sirsak (Tabel 1).
Kemudian dilakukan pengenceran pada masing-masing perbandingan sehingga diperoleh larutan sampel dengan konsentrasi (2, 4, 6, 8, 10, 12 ppm). Penentuan aktivitas antioksidan masing-masing konsentrasi dipipet 1,5 mL larutan sampel kemudian ditambahkan 3,0 mL larutan DPPH $40 \mathrm{ppm}$. Campuran tersebut diinkubasi pada suhu ruang. Kemudian campuran dimasukkan dalam kuvet, dan diukur absorbansinya.

\section{Pembuatan dan pengukuran larutan kontrol}

Dipipet $1,5 \mathrm{~mL}$ etanol $96 \%$, ditambahkan 3,0 mL larutan DPPH 40 ppm, campuran dimasukkan dalam kuvet, diukur absorbansinya pada panjang gelombang maksimum.

\section{Pengukuran aktivitas antioksidan vitamin $\mathbf{C}$}

Ditimbang 10,0 mg vitamin C larutkan dengan 100,0 mL etanol $96 \%$, hingga diperoleh konsentrasi 100 ppm. Kemudian lakukan pengenceran dari 100 ppm sampai didapatkan konsentrasi 2, 3, 4, 5 dan 6 ppm. Pengukuran aktivitas antioksidan setiap konsentrasi dipipet 1,5 mL ditambah 3,0 mL larutan DPPH 40 ppm. Campuran dikocok kemudian diinkubasi pada suhu ruang. Kemudian campuran dimasukkan dalam kuvet dan diukur absorbansinya.

\section{HASIL DAN PEMBAHASAN}

Maserasi merupakan metode pengekstrakan simplisia dengan menggunakan pelarut dengan beberapa kali atau pengadukan pada suhu kamar (Depkes RI, 2000). Pengadukan bertujuan untuk menjaga adanya derajat perbedaan konsentrasi yang sekecil-kecilnya antara di dalam dan di luar sel. Melalui upaya ini, dapa dijamin keseimbangan bahan ekstraktif di dalam cairan yang lebih cepat. Keadaan diam selama

Tabel 1. Perbandingan volume untuk masing-masing kombinasi

\begin{tabular}{ccccc}
\hline Kombinasi & Daun kersen & Daun sirsak & Vol & Konsentrasi \\
\hline $1: 1$ & $12,5 \mathrm{ml}$ & $12,5 \mathrm{ml}$ & $50 \mathrm{ml}$ & $100 \mathrm{ppm}$ \\
$1: 2$ & $8,3 \mathrm{ml}$ & $16,7 \mathrm{ml}$ & $50 \mathrm{ml}$ & $100 \mathrm{ppm}$ \\
\hline $2: 1$ & $16,7 \mathrm{ml}$ & $8,3 \mathrm{ml}$ & $50 \mathrm{ml}$ & $100 \mathrm{ppm}$ \\
\hline
\end{tabular}


maserasi, menyebabkan turunnya perpindahan bahan aktif. Berikut ini data berupa hasil rendemen ekstrak daun kersen dan daun sirsak dari hasil percobaan yang dilakukan.

Uji fitokimia dilakukan untuk mengetahui senyawa-senyawa yang terkandung di dalam sampel yang diujikan. Hasil uji kualitatif fitokimia seperti yang disajikan di Tabel 3 .
Prosentase inhibisi vitamin $\mathrm{C}$ yang digunakan sebagai control dalam penelitian ini menunjukkan hasil regresi linier sebesar 0,9923 (Gambar 1).

Berdasarkan Gambar 1 diperoleh persamaan regresi linier $\mathrm{y}=4,4297 \mathrm{x}+21,691$, maka dapat diketahui nilai $\mathrm{IC}_{50}$ sebesar 6,9126 sehingga dikategorikan sangat kuat.

Tabel 2. Rendemen ekstrak daun kersen dan daun sirsak

\begin{tabular}{cccc}
\hline Bahan & Berat simplisia & Berat ekstrak & \% rendemen \\
\hline $\begin{array}{c}\text { Daun } \\
\text { kersen }\end{array}$ & 250 gram & 60,00 gram & $24 \%$ \\
$\begin{array}{c}\text { Daun } \\
\text { sirsak }\end{array}$ & 250 gram & 40,00 gram & $16 \%$ \\
\hline
\end{tabular}

Tabel 3. Hasil uji kualitatif fitokimia

\begin{tabular}{clcc}
\hline No & \multicolumn{1}{c}{ Uji } & Daun kersen & Daun sirsak \\
\hline 1. & Alkaloid: & & \\
& Dragendorf & positif & positif \\
& Mayer & positif & positif \\
& Wagner & positif & positif \\
2. & Flavonoid & positif & positif \\
3. & Saponin & positif & positif \\
4. & Tanin & positif & positif \\
5. & Steroid & positif & negatif \\
\hline
\end{tabular}

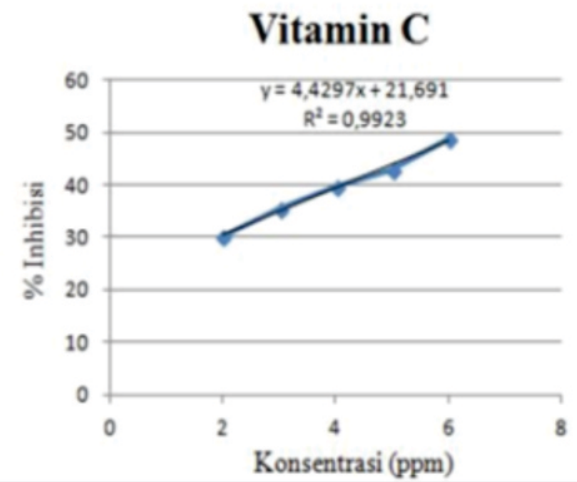

Gambar 1. Grafik \%inhibisi vit C

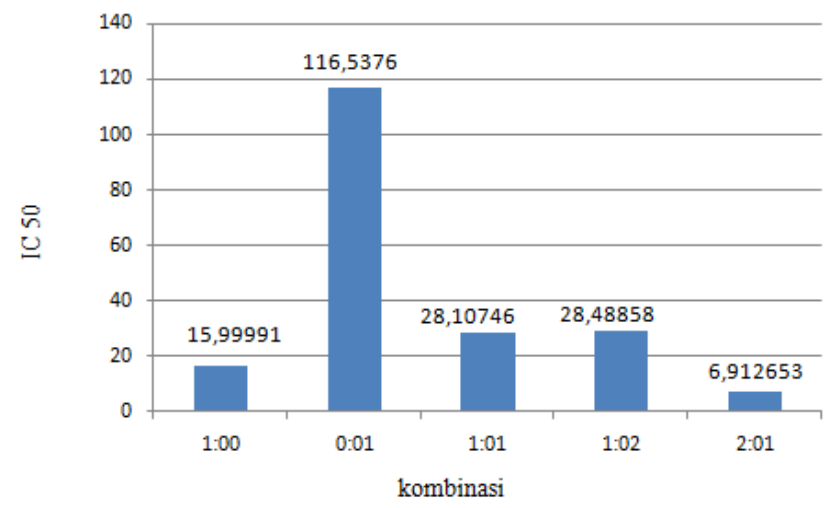

Gambar 2. Grafik $\mathrm{IC}_{50}$ bentuk tunggal daun kersen dan daun sirsak serta kombinasinya. 
Hasil penentuan aktivitas antioksidan yang paling kuat dalam meredam dampak radikal bebas yaitu bentuk kombinasi daun kersen dan sirsak dengan perbandingan 2:1 karena memiliki nilai $\mathrm{IC}_{50}$ kecil sehingga dikategorikan sangat kuat sedangkan yang paling lemah dalam meredam dampak radikal bebas yaitu bentuk tunggal daun sirsak karena memiliki nilai $\mathrm{IC}_{50}$ paling besar. Semakin kecil nilai $\mathrm{IC}_{50}$ maka semakin kuat dalam meredam dampak radikal bebas sedangkan semakin besar nilai $\mathrm{IC}_{50}$ maka semakin lemah dalam meredam dampak radikal bebas.

Seiring bertambahnya konsentrasi ekstrak maka absorbansi sampel akan menurun dan nilai tingkat inhibisi akan naik. Absorbansi sampel akan menurun di- karenakan elektron pada DPPH menjadi berpasangan dengan elektron sampel yang mengakibatkan warna larutan dari ungu berubah menjadi kuning pucat. Nilai tingkat inhibisi meningkat seiring meningkatnya konsentrasi sampel yang menghambat radikal bebas DPPH.

\section{KESIMPULAN}

Aktivitas antioksidan kombinasi ekstrak daun kersen (Muntingia calabura L.) dan daun sirsak (Anonna muricata L.) lebih kuat dibandingkan bentuk tunggal keduanya dengan kombinasi sangat kuat diperoleh dari perbandingan 2:1 dengan nilai $\mathrm{IC}_{50}$ sebesar 6,9126 ppm.

\section{UCAPAN TERIMA KASIH}

Terima kasih kepada Direktorat Riset dan Pengabdian Masyarakat yang telah mendanai pelaksanaan hibah penelitian dosen pemula tahun 2018 ini.

\section{DAFTAR PUSTAKA}

Arum, YP., Supartono., Sudarmin. 2012. Isolasi Dan Uji Daya Antimikroba Ekstrak Daun Kersen (Muntingia calabura L). Jurnal. Jurusan Kimia FMIPA UNNES. Semarang

Departemen Kesehatan Republik Indonesia. Direktorat Pengawasan Obat Tradisional. 2000. Parameter Standar Umum Ekstrak Tumbuhan Obat. Depkes RI. Jakarta

Handayani, H., Heppy, F., Yuniata. 2016. Ekstraksi Antioksidan Daun Sirsak Metode Ultrasonic Bath (Kajian Rasio Bahan: Pelarut dan Lama Ekstraksi). Jurnal. Universitas Brawijaya. Malang

Kuntorini, Evi Mintowati., Fitriana, Setya., Astuti, Maria Dewi. 2013. Struktur Anatomi Dan Uji Aktivitas Antioksidan Ekstrak Metanol Daun Kersen (Muntingia Calabura). FMIPA Universitas Lambung Mangkurat. Lampung

Romansyah, Y. 2011. Kandungan Senyawa Bioaktif Antioksidan Karang Lunak Sarcophyton sp. Alami dan Transplantasi si Perairan Pulau Pramuka Kepulauan Seribu, Skripsi, Departemen Ilmu dan Teknologi Kelauatan Fakultas Perikanan dan Ilmu Kelautan IPB. Bogor

Sumiyani dan Azminah. 2007. Perbandingan Aktivitas Peredaman Radikal Bebas 1,1 Diphenyl - 2- Picryl Hidrazyil (DPPH) Dari Ekstrak Etanol Wortel Lokal, Wortel Import, Suplemen Antioksidan Merck "TS" Dan Merck "SCV". Jurnal. Fakultas Farmasi Universitas Surabaya. Surabaya

Tambunan, Risma Marisi., Desmiaty, Yati., K.K, Kunthi Wida. 2012. Uji Pendahuluan Aktivitas Sitotoksik Dan Antioksidan Ekstrak Etanol Daun Sirsak (Annona muricataa Linn) dan Batang Brotowali (Tinospora crispa). Universitas Pancasila. Jakarta

Utomo, A.B., A. Suprijono, dan A. Risdianto. 2012. Uji Aktivitas Antioksidan Kombinasi Ekstrak Sarang Semut (Myrmecodia pendans) \& Ekstrak Teh Hitam (Camellia sinensis) dengan Metode DPPH (1,1-difenil-2pikrilhidrazil. Sekolah Tinggi Ilmu Farmasi Yayasan Pharmasi. Semarang

Zuhud. 2011. Kanker Lenyap Berkat Sirsak. Jakarta. PT Argo Media Pustaka 